\title{
In vitro Propagation of Banana (Musa paradisiaca L.) Plant Using Shoot Tip Explant
}

\author{
Girmay Mekonen ${ }^{1, a}$, Meseret Chimdessa Egigu ${ }^{2, b, *}$, Manikandan Muthsuwamy ${ }^{2, c}$ \\ ${ }^{I}$ Mekelle University, Department of Biotechnology, Mekele, Ethiopia \\ ${ }^{2}$ School of Biological Sciences and Biotechnology, Dire Dawa, Ethiopia \\ ${ }^{*}$ Corresponding author
}

\section{A R T I C L E I N F A B S T R A C T}

Research Article

Banana is a fruit crop which has high demand in Ethiopia, but its production is constrained by lack of disease free planting material with conventional propagation methods. For shoot initiation, shoot tip explants were cultured on MS medium supplemented with $0.5,1.0,1.5$ and $2.0 \mathrm{mg} / \mathrm{L}$ BAP. Similarly, MS medium supplemented with BAP at $1.0,1.5,2.0 \mathrm{mg} / \mathrm{L}$ in combination with IBA at

Received : $13 / 08 / 2019$

Accepted : 04/10/2021 0.25 and $0.50 \mathrm{mg} / \mathrm{L}$ were used for shoot multiplication. Half- strength MS medium augmented with IBA at 1.0, 2.0, 3.0 and $4.0 \mathrm{mg} / \mathrm{l}$ were used for root induction. MS medium without PGRs were used as controls. Finally, hardening of the in vitro derived plantlets was carried out in green house both in the primary and secondary acclimatization stages. Results showed that the highest shoot initiation percent (93.40\%), highest mean number of shoots per explant (4.67) and lesser day for

Keywords:

Acclimatization

In vitro

Micro-propagation

MS medium

Plant growth regulators shoot induction (11.00) were observed in explant cultured on MS + $1.0 \mathrm{mg} / \mathrm{L}$ BAP. With shoot multiplication, highest shooting percent (92.60\%), maximum number of shoots (7.67) and highest shoot length $(5.27 \mathrm{~cm})$ were recorded on $\mathrm{MS}+1.5 \mathrm{mg} / \mathrm{L} \mathrm{BAP}+0.5 \mathrm{mg} / \mathrm{L} \mathrm{IBA}$. The highest rooting percent $(93.40 \%)$, maximum root number per shoot (7.67) and highest root length $(11.00 \mathrm{~cm})$ were found on a half strength MS medium $+2.0 \mathrm{mg} / \mathrm{L} \mathrm{IBA}$. The survival rate of plantlets were $96.00 \%$ in coco peat substrate in primary acclimatization and $97.92 \%$ in forest soil, sand and manure substrates mixed at 3:2:1 ratio in secondary acclimatization. Overall, the result showed that the PGRs type, concentrations and combinations used are effective for mass propagation of banana variety studied in this experiment.

\footnotetext{
airmaymekonen21@gmail.com $\triangle$ drmkngl@gmail.com
}

\section{(D) https://orcid.org/0000-0002-7893-7704 iD https://orcid.org/0000-0002-5373-170X}

b@marakye311@gmail.com (i) https://orcid.org/0000-0001-5474-1515

(c) (9) () T) This work is licensed under Creative Commons Attribution 4.0 International License

\section{Introduction}

Banana (Musa paradisiaca, family Musaceae) is a fruit crop of the tropical and subtropical areas of the world grown in over 120 countries worldwide (Thangavelu and Mustaffa, 2012). It is being cultivated on approximately 10 million hectares with an annual world production estimated at 101.99 million tons (FAOSTAT, 2012). It serves as food source for more than 400 million people throughout the developing countries of the tropics and subtropics (Frison and Sharrock, 1999; Nelson et al., 2006). Banana ranks as the fourth major food crop after rice, wheat and maize and is considered as a poor man's apple in tropical and subtropical areas of the developing countries (Salvador et al., 2007). In terms of nutrition, banana is a thriving source of carbohydrate with calorific value of 67 calories per $100 \mathrm{~g}$ fruit and is one of the best well-liked and broadly traded fruits across the globe (Kumar et al., 2012). In Africa, banana provides more than a quarter of the carbohydrate requirements for over 70 million people. It is also the main staple food and a key component of food security in the Great Lakes region of Eastern Africa where it makes the highest contribution to household income (Smale and Tushemereirwe, 2007).

Ethiopia is one of the countries which has highly diverse agro-ecology that can grow different fruits where its massive areas are suitable for banana cultivation. Banana production in Ethiopia ranges from smallholding farmers to large commercial plantations under rain fed or with supplementary irrigation conditions (Kahessay et al., 2010). In Ethiopia, banana cultivation occupies the largest area $(53,956.16 \mathrm{ha})$ with production of $4,782,510$ quintals compared to other fruit crops. However, the global share of Ethiopia in banana export was only $0.02 \%$ which could be related to problems associated with low production and poor quality to meet export standards for international market (CSA, 2014).

Biotic factors such as attacks from nematodes, viruses, and insect pests are the major causes for low banana production in Ethiopia. The insect pests (fruit flies) and diseases caused by Xanthomonas wilt and Fusarium oxysporum, for example, are reported to be major 
challenges for banana production in Ethiopia (Mekonen, 2014). Furthermore, most commercial bananas are propagated vegetatively through suckers, which are collected from an existing field or from a multiplication plot planted only for the production of suckers. Conventional vegetative propagation of banana has its own limitations such as presence of diseased mother plants, low production, poor preservation of original plant genetic material (Ngomuo et al., 2014) and supply is season dependent (Hanumantharaya et al., 2009). In addition, due to the high degree of sterility and polyploidy of the edible varieties, only on average 5 to 10 or less suckers can be produced per year per plant depending upon variety and clone (Vuylsteke, 1998; Singh et al., 2011).

Generally, traditional propagation method is laborious; time consuming and inefficient to supply the increasing demand for healthy banana planting material. Banana production through conventional method also exposes the plant to different bacterial, fungal and viral diseases (Rahman et al., 2004). As a result, banana productivity decreases and the yield becomes very poor. To improve banana productivity and safeguard sustainable banana production, the use of clean and high quality planting material is crucial (Karembu et al., 2010). Thus, in order to overcome problems of conventional propagation and to avoid diseases transmitted by different pathogens, biotechnological methods can be used widely for the reliable propagation, genetic improvement, conservation and distribution of banana germplasms (Arvanitoyannis et al., 2008). In vitro propagation is one the applications of biotechnology that offers alternative and large number of plants using only a few explants (Dadjo et al., 2014).

Several researchers have reported the regeneration of Musa spp. through in vitro micro propagation (e.g., Uzaribara et al., 2015; Noor et al., 2017 and Singh et al., 2017). In vitro propagation of bananas offers excellent advantages relatively to traditional propagation methods which include large scale production of disease-free planting materials all year round, physiological uniformity, requires small space to multiply large number of plants and availability of disease-free material (Waman et al., 2014). Moreover, micro-propagated banana plants, in general establish more quickly, grow more vigorously, have a shorter and more uniform production cycle, and produce higher yields as compared to traditionally propagated bananas (Singh et al.,2013). Even though numerous reports are present on banana in vitro propagation, variation in propagation protocols may result in different results because of such factors as genotype difference, explant type, culture media composition, plant growth regulators (PGR) and culture environment (Vuylsteke, 1998). Therefore, this study was undertaken to evaluate efficiency of a protocol for of banana cv. Giant Cavendish.

\section{Materials and Methods}

\section{Description of the Study Area}

The experiment was conducted at Tigray Biotechnology Center, in the Quality Assurance Research and Development section, Mekelle city, Northern Ethiopia. The center was located $789 \mathrm{Km}$ North of Addis Ababa at an altitude of 1979 meter above sea level, $13^{\circ} 30^{\prime} 0^{\prime \prime} \mathrm{N}$ latitude and $39^{\circ} 28^{\prime} 11^{\prime \prime}$ E longitude.

\section{Stock Solution and Growth Media Preparation}

Stock solutions of the components of MS basal medium (Murashige and Skoog, 1962) were prepared by dissolving the appropriate and recommended amount of macronutrients, micronutrients and organic supplements in double distilled water. In the same way, plant growth regulators (BAP and IBA) stock solution were prepared using the proportion of $1 \mathrm{mg}$ : $1 \mathrm{ml}$ and stored in a refrigerator at $4^{\circ} \mathrm{C}$. In preparation of iron stock (1D), $\mathrm{FeSO}_{4} .7 \mathrm{H}_{2} \mathrm{O}$ and $\mathrm{Na}_{2}$.EDTA were dissolved in hot double distilled water separately. After dissolving, iron sulphate solution was added over $\mathrm{Na}_{2}$.EDTA solution in half liter beaker gently by stirring. EDTA makes Fe accessible at wide range of $\mathrm{pH}$ and overcomes its problem of precipitation and dissolvability after media preparation (Murashige and Skoog, 1962). Iron stock solution was protected from light by storing the solution in black bottle covered with aluminum foil.

The Murashige and Skoog (1962) medium used for shoot initiation, shoot multiplication and maintenance and regeneration of roots from multiplied shoots were prepared from its respective stock solutions of the MS basal medium and plant growth regulators. Sucrose $(30 \mathrm{~g} / \mathrm{l})$ was added to the medium solution before $\mathrm{pH}$ adjustment. The stock solutions were mixed properly using Magnetic stirrer. The $\mathrm{pH}$ of the medium was adjusted to 5.80 with $0.1 \mathrm{~N} \mathrm{HCl}$ and $0.1 \mathrm{~N} \mathrm{NaOH}$ followed by addition of $6 \mathrm{~g} / \mathrm{l}$ of agar. Sucrose $(30 \mathrm{~g} / 1)$ and agar $(6 \mathrm{~g} / \mathrm{l})$ were used because they had been the optimal concentrations from previous work with Musa species (Buah et al., 2010; Ahmed et al., 2014). Then 40 $\mathrm{ml}$ of the medium was dispensed in to a sterilized culture bottle and the media was autoclaved at $121^{\circ} \mathrm{C}, 15$ psi for 20 min. After autoclaving the media were allowed for solidification and kept for 72 hours in the media storage room before utilization for inoculation in order to check up the contamination status of the media.

\section{Plant Material Preparation and Surface Sterilization}

Young and healthy sword suckers of Musa paradisiaca cv. Giant Cavendish were used as experimental plant material in this study. The explant was collected from healthy field grown banana mother plants of Tigray Biotechnology Research Center banana propagation nurseries. The pseudo stems at the lower parts of the suckers containing meristems were used as explants. The sword suckers containing meristems were carefully detached from field grown fruiting banana plants. Then the selected and collected sword suckers were brought into the plant tissue culture laboratory and transplanted in controlled greenhouse until used. Then the corm tissue, roots, leaf sheathes and outer tissues of the suckers were trimmed and removed from the pseudo stem by sharp knife with the young leaves near the shoot tip meristem was left to about 3-4 cm.

After removing the outer sheaths of the suckers and collection of the sword suckers, the suckers were thoroughly washed with tap water for 20 minutes followed by detergent soup solution for 20 minutes to remove adherent soils. Then the explants were washed thoroughly with sterile distilled water four times so that no chemical residues are remaining. The explants were then surface sterilized in a combination of fungicide and bactericide of kocide, baylton and redimol (each $0.25 \mathrm{~g} / 100 \mathrm{ml}$ of distilled water) for 20 minutes followed by soaking in $2 \%$ 
$\mathrm{NaOCl}$ with two drops of Tween 20 (wetting agent) for 10 minutes. Furthermore, the sword sucker tips were treated with $0.1 \% \mathrm{HgCl}_{2}$ in laminar air flow chamber for $5 \mathrm{~min}$ as reported by Sumalatha (2016). After each step of sterilization, the explants were rinsed with sterile double distilled water four times to remove traces of surface sterilizing chemicals. Finally the surface sterilized shoottip explants were reduced to $2 \mathrm{~cm}$ size by removing the outer layers of corm and leaf sheaths using sterilized forceps and scalpel and inoculated under clean conditions.

\section{Establishment of the Explant in Culture Medium}

After complete sterilization, the surface sterilized and excised shoot tips were inoculated to shoot initiation media comprising of MS basal medium supplemented with different concentrations of BAP $(0.5,1.0,1.5$ and 2.0 $\mathrm{mg} / \mathrm{l})$. MS basal medium without plant growth regulator (PGR) was used as a control. Therefore, the total number of treatments used at this stage were 5 with 3 replications arranged randomly. The cultures were kept in a dark room for three days to prevent the blackening of the initiated sucker produced during the step wise removal of the covering leaf primordial. Then the initiated cultures were incubated and maintained for four weeks with a photoperiod of 16/8h light/dark using cool white fluorescent lamps (photon flux density, $40 \mu \mathrm{mol} \mathrm{m} \mathrm{m}^{-2} \mathrm{~s}^{-1}$ irradiance), at a temperature of $25 \pm 2^{\circ} \mathrm{C}$ and relative humidity of greater than $75 \%$ in a growth room. Finally the initiation response, initiated shoot numbers per explant and average days taken for shoot initiation were recorded.

\section{Multiplication Stage}

For multiple shoot formation, the clean and healthy shoots regenerated from the initiated shoot tip sword sucker were divided longitudinally into two or three parts and transferred to full strength MS medium supplemented with different concentrations $(1,1.5,2 \mathrm{mg} / \mathrm{L})$ of BAP each combined with 0.25 and $0.5 \mathrm{mg} / \mathrm{L}$ of IBA. As a carbon source and solidifying agent, $30 \mathrm{~g} / \mathrm{L}$ of sucrose and $6 \mathrm{~g} / \mathrm{L}$ of agar, respectively were also added. MS medium without PGRs was used as a control. Therefore, 7 treatments containing each 9 bottles with 3 replications arranged randomly on the culture media were used. Then the cultures were incubated and maintained in a growth room for four weeks at a temperature of $25 \pm 2{ }^{\circ} \mathrm{C}$ with a photoperiod of $16 \mathrm{hr}$ per day provided by white florescent tube and each required data of this stage was recorded.

\section{Rooting Stage}

For root induction, the in vitro developed healthy banana shoots were separated and transferred individually to half strength MS medium supplemented with $30 \mathrm{~g} / \mathrm{L}$ of sucrose and various concentrations of IBA $(1.0,2.0,3.0$ and $4.0 \mathrm{mg} / \mathrm{L})$. Activated charcoal at $0.3 \mathrm{~g} / \mathrm{L}$ for each rooting treatments were also added (Gubbuk and Pekmezci, 2004). Half-strength MS medium devoid of any plant growth regulator was used as a control. The total number of treatments that was used in rooting stage was 5 with 3 replications arranged randomly. The inoculated cultures were then incubated and maintained for four weeks in a growth room at a temperature of $25 \pm 2^{\circ} \mathrm{C}$ and $16 / 8$ hour photoperiod provided by cool-white fluorescent tube. After four weeks, the rooting percentage, the number and length of the regenerated roots were recorded.

\section{Acclimatization Stage}

The in vitro regenerated and rooted banana plantlets were taken out from culture bottles using sterilized forceps with great care to avoid any damage to the plantlets root system. Then the roots were carefully washed thoroughly with slightly warm running tap water to remove the adherent traces of agar and medium attached to the roots. Immediately after washing, the in vitro raised banana plantlets were covered by wet newspaper and transferred to green house for primary hardening and transplanted carefully using sharp wooden sticks on trays containing moisture coco peat and covered with transparent plastic bags in the green house for seven days in order to maintain high humidity ( 80 to $90 \%$ ) and reduce light intensity. After seven days, the plastic cover was removed and the humidity was gradually decreased to $50-60 \%$, light intensity raised up to normal and temperatures were increased to $27 \pm 2^{\circ} \mathrm{C}$ up to 40 days. The survival rate of the successfully acclimatized plants at primary hardening were computed. Then, plantlets were later transferred to bigger plastic pots for secondary hardening that was filled with forest soil, sand and manure in different ratios. Then the percentage of successfully survived banana plantlets from the total transplanted banana plantlets in green house were computed.

\section{Data Analysis}

The experiment was arranged in a completely randomized design and data was subjected to one way analysis of variance (ANOVA) using the SAS software packages (version 9.2) and the significant differences among the treatment mean values were evaluated using Fisher's least significant differences (LSD) at 5\% level of significance.

\section{Results and Discussion}

\section{Effects of Different Concentration of BAP on Number of Days for Shoot Initiation and Percent Shoot Initiated}

In the present study, the properly surface sterilized shoot tips obtained from the sword suckers of banana cv. Giant Cavendish were directly inoculated on full strength MS medium supplemented with different concentrations of BAP $(0.51 .0,1.5$ and $2.0 \mathrm{mg} / \mathrm{l})$ for in-vitro shoot initiation. Results showed that percent of shoot initiated per explant was significantly $(\mathrm{P}<0.001)$ varied between treatments with PGRs treatment at all concentration levels significantly surpassing values observed in control (Table 1). Among the different concentrations of BAP tested, significantly highest shoot initiation percentage (93.40\%) was observed on full strength MS medium fortified with $1.0 \mathrm{mg} / \mathrm{L}$ BAP followed by $73.40 \%$ shoot initiation MS medium supplemented with $1.5 \mathrm{mg} / \mathrm{L}$ BAP (Table 1). This indicates that shoot initiation from banana shoot tip explants is cytokinin concentration dependent. Similar research done by Ali et al. (2011) supports the result of this study as they obtained best shoot formation response $(100 \%)$ using banana shoot tip meristem explant cultured on MS medium fortified with $1.0 \mathrm{mg} / \mathrm{L} \mathrm{BAP.} \mathrm{On} \mathrm{the}$ contrary, authors such as Venkatachalam et al. (2007) and Bairu et al. (2008) reported that $5 \mathrm{mg} / \mathrm{L}$ BAP was the most effective concentration for in vitro shoot induction and proliferation of many banana cultivars. Variation between 
the present result and theirs may be due to difference in the genotypes we used. Arinaitwe et al. (2000) previously reported that same explants from different genotypes can differentially respond to different concentrations of the same hormone. Moreover, Sipen and Davey (2012); Rahman et al. (2013) and Iqbal et al. (2013) reported that the in vitro shoot regenerative capacity of banana is highly genotype specific and greatly influenced by cytokinin concentrations in shoot inducing medium.

Likewise, days to shoot initiation was significantly $(\mathrm{P}<0.001)$ varied between treatments with explants treated with PGR at all concentration levels took fewer days for shoot initiation than the control (MS without PGR) (Table 1). Among the various concentrations of BAP, shoot tip explants cultured on MS medium supplemented with 1.0 $\mathrm{mg} / \mathrm{L}$ BAP took lesser number of days (11.00 days after inoculation) compared to the rest of the treatments. On the other hand, the exogenous BAP free MS basal medium took significantly more days (22 days) for shoot initiation and establishment (Table 1). This indicates that the endogenous plant growth hormones available in the explants may not be sufficient to induce shoots. The present result is in accordance with the findings of Shagufta et al. (2011) and Ali et al. (2011) who recorded shoot initiation within 10.6 days after inoculation using MS medium supplemented with $1.0 \mathrm{mg} / \mathrm{L}$ of BAP.

\section{Effects of PGRs on Shoot Multiplication}

Different concentrations and combinations of cytokinin and auxin in culture media are key factors which determine successful shoot multiplication. Previously, trials on multiplication of several cultivars of banana have been reported (Al-Amin et al., 2009; Hapsoro et al., 2010; Ali et al., 2011). However, the optimum medium for shoot multiplication of each cultivar was different. Results of this study showed that shoot multiplication was varied significantly $(\mathrm{P}<0.05)$ between $\mathrm{PGR}$ treated shoots and control (with no PGR) (Table 2). The result revealed that the percentage of shoot response under various concentrations and combinations of BAP and IBA was found in the range of 22.22 to $92.60 \%$ (Table. 2). Significantly highest shoot response $(92.60 \%)$ was found on the treatment combination of $1.5 \mathrm{mg} / \mathrm{L} \mathrm{BAP}$ and 0.5 $\mathrm{mg} / \mathrm{L}$ of IBA (with mean of shoot formed/explants of 8.33); followed by MS medium fortified with $1.0 \mathrm{mg} / \mathrm{L} \mathrm{BAP} \mathrm{+}$ $0.25 \mathrm{mg} / \mathrm{L}$ IBA which accounted for $66.67 \%$ (with mean 6.00 of shoot formed/explants) compared to the control and other treatments. The lowest mean shoot percentage (22.22 $\%)$ was observed on the MS medium devoid of PGRs.
Benzyl amino purine (BAP) combined with auxins (indole acetic acid and indole butyric acetic acid) exhibit synergistic effect on shoot formation and hence has also been used by a number of researchers (Jafari et al., 2011; Sipen and Davey, 2012; Ngomuo et al., 2013).

Variable number of shoots were produced in MS media supplemented with different concentrations of BAP and IBA. Among the different concentrations analyzed, significantly maximum mean number of shoots per explant (7.67 \pm 0.58 ) were obtained on the treatment combination of MS medium supplemented with $1.5 \mathrm{mg} / \mathrm{L}$ BAP and 0.5 $\mathrm{mg} / \mathrm{L}$ IBA; followed by MS medium fortified with 1.0 $\mathrm{mg} / \mathrm{L} \mathrm{BAP}+0.25 \mathrm{mg} / \mathrm{L} \mathrm{IBA}(4.67 \pm 0.58)$ (Table 2$)$. In addition, the shoots obtained on these treatments were morphologically better having well differentiated and relatively taller and deep green appearance. Although MS $+2.0 \mathrm{mg} / \mathrm{L} \mathrm{BAP}+0.25 \mathrm{mg} / \mathrm{L} \mathrm{IBA}$, and $\mathrm{MS}+2.0 \mathrm{mg} / \mathrm{L}$ $\mathrm{BAP}+0.5 \mathrm{mg} / \mathrm{L} \mathrm{IBA}$ resulted in less mean number of shoot, they were also significantly better than the control.

Overall, the present study showed that BAP was effective when combined with IBA for optimum shoot multiplication from shoot tips of the banana cultivar used in this experiment. These findings are similar with that of Gubbuk and Pekmezcu (2004) and Ngomuo et al. (2013) who reported that apart from the genotypes of the cultivar, shoot multiplication and proliferation are also influenced by exogenous cytokinin concentration in growth medium. On the contrary to the present result, Rabbani et al. (1996) and Ali et al. (2011) found highest number of shoots per explants (3.11 \pm 0.66 and $5.8 \pm 0.33)$ with $5.0 \mathrm{mg} / \mathrm{l}$ of BAP $+\mathrm{Kn}$, and $1.5 \mathrm{mg} / \mathrm{l}$ of BAP after four weeks, respectively. The source of variation may be due to the different concentrations of BAP (cytokinin) and IBA (auxins), their combinations and genotype of the cultivar. This result is in agreement with the findings of Arinaitwe et al. 2000; Rahman et al. (2013) and Iqbal et al. (2013) who reported that shoot formation and multiplication in banana plants depend on the concentration of cytokinin used and genotype of the cultivar.

With respect to shoot length, the maximum length $(5.27 \pm 0.11 \mathrm{~cm})$ was observed in the treatment combinations of full strength MS medium supplemented with $1.5 \mathrm{mg} / \mathrm{l} \mathrm{BAP}+0.5 \mathrm{mg} / \mathrm{l}$ IBA followed by the treatment combinations of full strength MS medium augmented with $1.0 \mathrm{mg} / \mathrm{L} \mathrm{BAP}+0.25 \mathrm{mg} / \mathrm{L} \mathrm{IBA}$, which produced $3.92 \pm 0.32 \mathrm{~cm}$. In contrast, the shorter shoot length $(1.38 \pm 0.34 \mathrm{~cm})$ was recorded on MS medium devoid of growth hormones (control) similar to the finding of ALAmin et al. (2009) who recorded $1.05 \mathrm{~cm}$ shoot length on hormone free MS medium.

Table 1. Effect of different concentration of BAP (Mean $\pm \mathrm{SD}, \mathrm{n}=3$ ) on in vitro shoot initiation and establishment of Banana cv. Giant Cavendish

\begin{tabular}{l|ccc}
\hline $\begin{array}{c}\text { BAP concentration } \\
(\mathrm{mg} / \mathrm{L})\end{array}$ & $\begin{array}{c}\text { Average Shoot } \\
\text { Initiation }(\%)\end{array}$ & $\begin{array}{c}\text { Mean of Initiated } \\
\text { shoots/explant }\end{array}$ & $\begin{array}{c}\text { Average Days taken } \\
\text { for shoot initiation }\end{array}$ \\
\hline 0.00 & $20.00 \pm 0.00^{\mathrm{d}}$ & $1.00 \pm 0.00^{\mathrm{d}}$ & $22.00 \pm 1.00^{\mathrm{a}}$ \\
0.5 & $46.60 \pm 0.58^{\mathrm{c}}$ & $2.33 \pm 0.58^{\mathrm{c}}$ & $18.00 \pm 0.00^{\mathrm{b}}$ \\
1.0 & $93.40 \pm 0.58^{\mathrm{a}}$ & $4.67 \pm 0.58^{\mathrm{a}}$ & $11.00 \pm 1.00^{\mathrm{d}}$ \\
1.5 & $73.40 \pm 0.57^{\mathrm{b}}$ & $3.00 \pm 0.00^{\mathrm{b}}$ & $15.00 \pm 1.00^{\mathrm{c}}$ \\
2.0 & $40.00 \pm 0.68^{\mathrm{c}}$ & $2.00 \pm 0.00^{\mathrm{c}}$ & $16.00 \pm 2.00^{\mathrm{bc}}$ \\
CV & & 14.04 & 7.21 \\
LSD & & 0.66 & 2.15 \\
\hline
\end{tabular}

Means in the column that are followed by the same letter (s) are not significantly different at 5\% significance level using Fisher's LSD test, CV= coefficient of variation (\%), LSD=Least Significant Difference, $\%=$ Percentage. 
Table 2. Effect of Different Concentrations and Combination of BAP and IBA on in vitro Shoot Multiplication of Banana CV. Giant Cavendish.

\begin{tabular}{lc|ccc}
\hline \multicolumn{2}{c|}{$\begin{array}{c}\text { Concentration of PGRs } \\
(\mathrm{mg} / \mathrm{l})\end{array}$} & $\begin{array}{c}\text { Mean Percent of } \\
\text { shooting }\end{array}$ & $\begin{array}{c}\text { Mean of shoot №/ } \\
\text { shoot let }\end{array}$ & $\begin{array}{c}\text { Mean of Shoot } \\
\text { Length/shoot let }(\mathrm{cm})\end{array}$ \\
\hline BAP & IBA & & & \\
0 & 0 & $22.22 \pm 0.00^{\mathrm{e}}$ & $1.00 \pm 0.00^{\mathrm{e}}$ & $1.38 \pm 0.34^{\mathrm{f}}$ \\
1 & 0.25 & $66.67 \pm 1.00^{\mathrm{b}}$ & $4.67 \pm 0.58^{\mathrm{b}}$ & $3.92 \pm 0.32^{\mathrm{b}}$ \\
1.5 & 0.25 & $37.04 \pm 0.58^{\mathrm{cd}}$ & $2.33 \pm 1.15^{\mathrm{cd}}$ & $2.21 \pm 0.36^{\mathrm{d}}$ \\
2 & 0.25 & $25.93 \pm 0.58^{\mathrm{de}}$ & $2.00 \pm 0.00^{\mathrm{d}}$ & $1.67 \pm 0.18^{\mathrm{ef}}$ \\
1 & 0.5 & $40.74 \pm 0.58^{\mathrm{c}}$ & $3.00 \pm 0.00^{\mathrm{c}}$ & $2.87 \pm 0.15^{\mathrm{c}}$ \\
1.5 & 0.5 & $92.60 \pm 0.58^{\mathrm{a}}$ & $7.67 \pm 0.58^{\mathrm{a}}$ & $5.27 \pm 0.11^{\mathrm{a}}$ \\
2 & 0.5 & $25.33 \pm 0.58^{\mathrm{de}}$ & $2.00 \pm 0.00^{\mathrm{d}}$ & $2.03 \pm 0.15^{\mathrm{de}}$ \\
& $\mathrm{M}(\%)$ & & 6.50 & 9.13 \\
& & 0.94 & 0.44 \\
\hline
\end{tabular}

Means in the column that are followed by the same letter (s) are not significantly different at 5\% significance level using Fisher's LSD test, CV= coefficient of variation (\%), LSD=Least Significant Difference.

The treatment $2.0 \mathrm{mg} / \mathrm{L} \mathrm{BAP}+0.25 \mathrm{mg} / \mathrm{L}$ IBA $(1.67 \pm 0.18 \mathrm{~cm})$ produced shorter shoot length which is not significantly different from control treatment (Table 2). Reddy et al. (2014) obtained $5.68 \pm 0.3 \mathrm{~cm}$ mean shoot length when shoot tip explants were cultured in MS medium fortified with $2.0 \mathrm{mg} / \mathrm{L} \mathrm{BAP}$ which is partially similar to the present result.

\section{Effect of IBA on In Vitro Rooting of Regenerated Banana Plantlets}

A good and healthy root system is essential for successful acclimatization of the in vitro derived shoots and subsequent growth in the fields as roots assist the absorption of nutrients from the soil (Xiansong, 2010). Therefore, the in vitro raised and proliferated shoots were excised and transferred in to half strength MS medium supplemented with different concentration of IBA (1.0, $2.0,3.0$ and $4.0 \mathrm{mg} / \mathrm{l})$ for healthy root induction and development. Results showed that root induction was varied significantly between PGR treated shoots and control (with no PGR). Among the various concentrations of IBA investigated, the highest root induction percentage (93.40\%) was achieved on $1 / 2$ strength MS medium supplemented with $2.0 \mathrm{mg} / \mathrm{L} \mathrm{IBA}$ and the lowest $(33.40 \%)$ was found on $1 / 2$ strength MS medium supplemented with $4.0 \mathrm{mg} / \mathrm{L}$ IBA (Table 3). Previously, Rahman et al. (2013) and Saraswathi et al. (2014) reported the effectiveness of IBA on development of roots in banana cultivars. Raut and Lokhande (1989) mentioned the importance of exogenous auxin application for root formation, though degree of effectiveness varies with cultivar and concentration used. Result of the present study is more or less similar with that of Rahman et al. (2013) and Devendrakumar et al. (2013) who found highest rooting percentage $(96 \%$ and $94.30 \%$, respectively) when shoots were cultured on a $1 / 2 \mathrm{MS}$ medium fortified with $1.0 \mathrm{mg} / \mathrm{L}$ IBA and $0.5 \mathrm{mg} / \mathrm{L} \mathrm{IBA}$ in cv. Agnishwar and Cavendish dwarf, respectively. However, the slight difference seen between theirs and the current result may be due to the variation of genotype of the plant material. Completely, no root formation was observed on the hormone free half strength MS medium, suggesting that exogenous application of auxin is mandatory for effective rooting as endogenous auxin could be too low for root induction.
Results of rooting experiment also showed that number of roots per shoot and root length per shoot were significantly $(\mathrm{P}<0.05)$ varied between treatments (Table 3$)$. Among the different concentrations of IBA tested, the highest mean root number $(7.67 \pm 0.58)$ and root length $(11 \pm 1.00)$ were observed at $2 \mathrm{mg} / \mathrm{L}$ of IBA followed by $5.33 \pm 0.58$ of root number and $8.00 \pm 00$ root length at $3 \mathrm{mg} / \mathrm{L}$ of IBA. The lowest values of both root number and root length per shoot were obtained at $4 \mathrm{mg} / \mathrm{L}$ of IBA with treatment without PGR actually was totally non-responsive (Table 3). The present result is in agreement with Rai et al. (2014) who noted that $2 \mathrm{mg} / \mathrm{L}$ IBA produced maximum number of roots with a lot of root hairs. Similarly, Lohidas and Sujin (2015) also found $8.66 \pm 0.58$ number of roots on $1 / 2$ strength MS medium supplemented with $2.0 \mathrm{mg} / \mathrm{L}$ IBA. Moreover, the present result is at a par with the finding of Rashmid and Babu (2017) who obtained 7.62 roots per plantlet on Banana cv. Rajapuri Bale (AAP) on a medium supplemented with $2.0 \mathrm{mg} / \mathrm{L}$ of IBA. With respect to root length the present result is nearly similar with that of Uzirabera et al. (2015) who found the highest root length $(8.99 \mathrm{~cm})$ at $1.5 \mathrm{mg} / \mathrm{L}$ IBA on banana cv. Kamalapur Red. However, the current result is not in agreement with that of Davendrakumar et al.( 2013) who reported that $0.5 \mathrm{mg} / \mathrm{L}$ IBA produced the highest root number (6 root/plantlet) in Cavendish $d$ warf variety. The cause of variation may be the difference in cultivars we used as different cultivars may respond to varying concentration of the same hormone. Dihiz et al. (2007) also reported that consistently higher number of roots are produced when MS media is augmented with moderate concentration of IBA, NAA and activated charcoal. In this study, $2.0 \mathrm{mg} / \mathrm{L}$ IBA supplemented to $1 / 2 \mathrm{MS}$ media showed maximum number of roots per plantlets. Overall, from the present result of rooting parameters, half strength MS medium augmented with $2.0 \mathrm{mg} / \mathrm{L}$ of IBA showed good rooting performance and was found to be the most effective for in vitro rooting of banana which is in line with the report of Lohidas and Sujin (2015).

\section{Acclimatization of the In Vitro Raised Plantlets}

Pati et al. (2013) reported that maximum mortality of micro propagated plants occurs during acclimatization phase as plantlets undergo rapid and extreme changes in morphological and physiological functioning, histological 
and biochemical changes in in vivo. To resolve this problem, acclimatization is essential for the survival and successful establishment of in vitro raised plantlets (Deb and Imchen, 2010). Therefore, it is necessary to acclimatize the in vitro raised banana plantlets in two stages viz. primary and secondary hardening. Results showed that the survival rate of in-vitro regenerated plantlets at primary acclimatization was $96.00 \%$ (Table 4)) in green house. The present result is in line with the finding of Uzaribara et al. (2015) who recorded 95\% survival rate of in vitro produced red banana (Musa acuminata) plantlets on a coco peat at primary acclimatization. Similarly, Rai et al. (2014) also recorded $96 \%$ survival rate of in vitro raised plantlets on a mixture of coco peat and sand under greenhouse conditions which is at a par with the current result. However, mortality of the $4 \%$ of plantlets at the primary hardening may be due to the injuries to the root system, sensitivity of the in vitro plantlets to sudden exposure to harsh environmental conditions and excessive evaporation.

After primary hardening, the in vitro raised banana plantlets were transferred to a bigger plastic pot that contained a mixture of forest soil, sand and manure in different ratios for further hardening before field transfer and they were successfully acclimatized. Result showed that survival rate of in-vitro regenerated plantlets on the pot mixtures of forest soil: sand: manure in the ratio of $3: 2: 1 ; 3: 2: 2$ and $3: 1: 2$ were $97.92 \%, 93.75 \%$ and $95.83 \%$, respectively.

Though highest survival percentage $(97.92 \%)$ was found on the substrate mixture of forest soil: sand and manure in the ratio of $3: 2: 1$, there was good plantlet survivability in secondary hardening under all substrate mixtures which may be because of the in vitro produced plantlets were reduced their sensitivity to sudden exposure of tough environmental conditions in the primary acclimatization stage. The present result was in agreement with Devalakere et al. (2019) who recorded $97.17 \%$ survival rate during secondary hardening processes of banana cv. Kamalapur Red (AAA). Moreover, successful acclimatization and survival percentage of in vitro produced banana plantlets ranging from $80-100 \%$ under greenhouse conditions have been reported by several workers (Rahman et al., 2013; Ahmed et al ., 2014; Hossain et al., 2016).

\section{Acknowledgements}

This research was supported by the Ethiopian Ministry of Education. The authors would like to thank the Tigray Biotechnology Center (TBC) for providing us with full laboratory facilities.

Table 3. Effect of different concentrations of IBA on in vitro rooting of Giant Cavendish Banana along with $1 / 2$ strength MS medium

\begin{tabular}{|c|c|c|c|}
\hline $\begin{array}{c}\text { Concentration of } \\
\text { IBA }(\mathrm{mg} / \mathrm{L})\end{array}$ & $\begin{array}{l}\text { Mean Percent of } \\
\text { Rooting Response }\end{array}$ & $\begin{array}{c}\text { Mean Root } \\
\text { No/plantlets }\end{array}$ & $\begin{array}{l}\text { Mean Root } \\
\text { Length }(\mathrm{cm})\end{array}$ \\
\hline 0.00 & $0.00 \pm 0.00^{\mathrm{e}}$ & $0.00 \pm 0.00^{\mathrm{d}}$ & $0.00 \pm 0.00^{\mathrm{d}}$ \\
\hline 1.00 & $73.40 \pm 0.58^{b}$ & $4.67 \pm 0.57^{b}$ & $7.89 \pm 1.17^{b}$ \\
\hline 2.00 & $93.40 \pm 0.58^{\mathrm{a}}$ & $7.67 \pm 0.58^{\mathrm{a}}$ & $11.00 \pm 1.00^{\mathrm{a}}$ \\
\hline 3.00 & $53.40 \pm 0.58^{c}$ & $5.33 \pm 0.58^{b}$ & $8.00 \pm 0.00^{\mathrm{b}}$ \\
\hline 4.00 & $33.40 \pm 0.58^{\mathrm{d}}$ & $1.33 \pm 0.57^{\mathrm{c}}$ & $3.22 \pm 0.96^{\mathrm{c}}$ \\
\hline $\mathrm{CV}(\%)$ & & 13.58 & 13.45 \\
\hline LSD & & 0.93 & 1.47 \\
\hline
\end{tabular}

Means in the column that are followed by the same letter (s) are not significantly different at 5\% significance level using Fisher's LSD test, CV= coefficient of variation (\%), LSD=Least Significant Difference, \%= Percentage.

Table 4. Survival rate of the in vitro raised plantlets at primary and secondary acclimatization

\begin{tabular}{l|lccc}
\multicolumn{1}{c|}{ Substrate used } & \multicolumn{1}{c}{$\begin{array}{c}\text { Acclimatization } \\
\text { stage }\end{array}$} & $\begin{array}{c}\text { Total № } \\
\text { of plantlets used }\end{array}$ & $\begin{array}{c}\text { No of } \\
\text { plantlets survived }\end{array}$ & $\begin{array}{c}\text { Survival } \\
\text { rate }(\%)\end{array}$ \\
\hline Coco peat & Primary & 150 & 144 & 96.00 \\
forest soil: sand: manure( 3:2:1) & Secondary & 48 & 47 & 97.92 \\
Forest soil: sand: manure(3:2:2) & Secondary & 48 & 45 & 93.75 \\
Forest soil: sand: manure(3:1:2) & Secondary & 48 & 46 & 95.83 \\
\hline
\end{tabular}

\section{References}

Ahmed S, Sharma A, Bhushan B, Singh AK, Wall VK. 2014. Effect of carbohydrate source, $\mathrm{pH}$ and supporting media in vitro rooting of banana (Mussa spp.) cv. Gradnaine plantlets. Afr. J. Agric. Res., 9:1135-1140.

Al-Amin MD, Karim MR, Amin MR. 2009. In vitro micro propagation of banana. Bangladesh j. agric. res., 34: 645-659.

Ali A, Sajid A, Naveed NH, Majid A, Saleem A, Khan UA, Jafery FI, Naz S. 2011. Initiation, proliferation and development of micro-propagation system for mass scale production of banana through meristem culture. Afr. J. Biotechnol., 10:15731-15738.

Arinaitive G, Rubaihago PR, Magambo MJS. 2000. Proliferation rate effects of cytokinins on banana (Musa spp.) Cultivars. Hort. Sci., 86: $13-21$.
Arvanitoyannis IS, Mavromatis AG, Grammatikaki AG, Sakellariou M. 2008. Banana: Cultivars, biotechnological approaches and genetic transformation. International Journal of Food Science and Technology, 43: 1871-1879.

Bairu MW, Strik WA, Dolezal K, Staden JV. 2008. The Role of Topolins in Micro Propagation and Soma-clonal Variation of Banana Cultivars 'Williums' and 'Grand Naine' (Musa spp. AAA). PLANT CELL TISS ORG, 95: 373-379.

Buah JN, Danso E, Taah KJ, Abole EA, Bediako EA, Asiedu J, Baidoo R. 2010. The effects of different concentrations of cytokinins on the in vitro multiplication of plantain (Musa sp.). Biotechnology, 9:343-347.

CSA. 2014. Central statistical agency agricultural sample survey. Addis Ababa. 
Dadjo C, Kahia J, Sila D, Muthuri C, Diby L, Kouame C. 2014. Induction and regeneration of somatic embryos from Vitex doniana (Lamiaceae) leaf explants. Int. J. Biotechnol. Mol. Biol. Res., 6:28-34.

Deb CR, Imchen T. 2010. An efficient in vitro hardening technique of tissue culture raised plants. Biotechnology, 9: 79-83.

Devalakere P, Gurunath R, Ryavalad S, Kustagi G., Krishnappa K. 2019. In vitro Mass Propagation System in Banana Cv. Kamalapur Red (AAA). Res. J. Biotechnol., 14: 103 - 113.

Devendrakumar D, Anbazhagan M, Rajendran R. 2013. In Vitro propagation of Banana (Musa acuminate L.) cv. Cavandish Dwarf. International Journal of Research in Biomedicine and Biotechnology, 3: 44-46

Dihiz AL, Pradeep G, Sumu A. 2007. Effect of IBA and Activated Charcoal on in vitro culture of Banana. J. Agric. Res, 40: 114.

FAOSTAT .2012. Food and Agriculture Organization Statistical Division. Overview of World Banana Prolduction and Trade. The World Banana Economy, http://www.fao.org/3/y5102e/ y5102e04.htm [Accessed March, 2019].

Frison EA, Sharrock SL. 1999. The economic, nutritional and social importance of bananas in the world. In: Banana and food security. Proceedings of International Symposium on Bananas and Food Security, Douala, Cameroon (pp. 221-35).

Gübbük H,Pekmezci M. 2004. In vitro Propagation of Some New Banana Types (Musa spp.). TURK J Agric For, 28: 355-361.

Hanumantharaya MR, Kerutagi MG, Patil BL, Kanamadi VC, Basavaraj B. 2009. Comparative economic analysis of tissue culture banana and sucker propagated banana production in Karnataka. J. Agric Sci, 22: 810-815.

Hapsoro D, Alisan MI, Ismaryati T. 2010. Effects of benzyl adenine on in vitro shoot multiplication of banana (Musa paradisiaca Linn.) cv. Ambon Kuning and Tanduk. Proceed. International Seminar on Horticulture to Support Food Security.

Hossain MA, Rubel MH, Khondoker M, Nasiruddin KM, Fatematuz ZE. 2016. Influence of BAP and NAA on in vitro plantlet regeneration of local and exotic banana cultivars. J. Biosci. agric. res., 6: 553-564.

Iqbal MM, Muhammad A, Hussain I, Bilal H. 2013. Optimization of in vitro micro propagation protocol for banana (Musa Sapientum L.) under different hormonal concentrations and growth media. Int. J. Agric. Res. Innov, 2:23-27.

Jafari N, Othman RY, Khalid N. 2011. Effect of BAP pulsing on in vitro shoot multiplication of Musa acuminate (banana) $\mathrm{cv}$. berangan. Afr. J. Biotechnol, 10:2446-2450.

Kahesaye B, Puskur R, Worku T, Hoekstra D, Azage T. 2010. Innovation in banana value chain development in Metema district, northwestern Ethiopia: Improving productivity and market success (IPMS) project experiences. Acta Horticulturae, 879: 129-139.

Karembu M, Otunge D, Wafula D. 2010. Developing a Biosafety Law: lessons from the Kenyan experience. ISAAA AfriCenter, Nairobi, Kenya.

Kumar KS, Bhowmik D, Duraivel S, Umadevi M. 2012. Traditional and medicinal uses of banana. J Pharmacogn Phytochem, 1: 51-63.

Lohidas J, Sujin D. 2015. Effect of growth hormones in the micro propagation of Banana cv. Matti. Plant Archives, 15: 307314.

Mekonen F. 2014. The history and future of banana in Arba Minch, Ethiopia. https://livesethiopia.wordpress.com/ 2014/02/25/banana-history/ [Accessed March 2019].

Murashige T, Skoog F. 1962. A revised medium for rapid growth and bio assays with tobacco tissue cultures. Physiol plant, 15: 473-497.

Nelson SC, Ploetz RC, Kepler AK. 2006. Musa species (banana and plantain). Species Profiles for Pacific Island Agroforestry, 15: 251-259.
Ngomuo M, Mneney E, Ndakidemi P .2014. The in vitro Propagation Techniques for Producing Banana Using Shoot Tip Cultures. Am J Plant Sci, 5:1614-1622.

Noor EEM., Sinniah UR, Swamy MK. 2017. Micro propagation of Musa acuminata Var. Zebrina (Van Houtte ex Planch.) nasution, an ornamental plant for the horticulture industry. Bangl J Bot, 46: 297-304.

Pati R, Mishra M, Chandra R, Muthukumar M. 2013. Histological and Biochemical Changes in Aegle marmelos Corr. before and after Acclimatization. Tree Genetics and Molecular Breeding, 3:12-18.

Rabbani MG, Au MH, Mondal MF. 1996. Effect of BAP and IBA on micro propagation of some banana cultivars. Bangladesh Horticulture, 25: 47-52.

Rahman MZ, Nasiruddin KM, Amin MA, Islam MN. 2004. In vitro response and shoot multiplication of banana with BAP and NAA. Asian Journal of Plant Sciences, 3: 406-409.

Rahman S, Biswas N, Hassan MM, Ahmed MG, Mamun ANK, Islam MR., Moniruzzaman M, Haque ME. 2013. Micro propagation of banana (Musa sp.) cv. Agnishwar by in vitro shoot tip culture. International Research Journal of Biotechnology, 4: 83-88.

Rai M, Mittal P, Kaur A, Kaur G, Gaur I, Singh C. 2014. In Vitro Regeneration of Banana Variety Grand Naine (G 9). Trends in Biosciences. 5: 176-179.

Rashmi G, Babu AG. 2017. Protocol for Tissue Culture Propagation of Banana Cv. Rajapuri Bale (AAB). International Journal of Science and Nature, 8: 892-897.

Raut RS, Lokhande VE. 1989. Propagation of plantain through meristem culture. Annals Plant Physiol, 3: 256-260.

Reddy D, Suvarna D, Rao DM. 2014. Effects of 6-Benzyl Amino Purine (6-BAP) on In Vitro Shoot Multiplication of Grand Naine (Musa Spp.). Int J Adv Biotechnol Res, 5: 36-42.

Salvador A, Sanz T, Fiszman SM. 2007. Changes in colour and texture and their relationship with eating quality during storage of two different dessert bananas. Postharvest Biol Tech, 43: 319-325.

Saraswathi MS, Praveena S, Uma S, Thangavelu R, Kannan G, Backiyarani S, Arivazhagan T. 2014. Development of an efficient micro propagation technique for Musa cv. Udhayam (ABB). Indian J Hortic, 71: 452-457.

Shagufta N, Aamir A, Anum S, Naima H, Abdul M, Asif S. 2011. Initiation, proliferation and development of micropropagation system for mass scale production of banana through meristem culture. Department of Biological Sciences, University of Sargodha. Afr. J Biotechnol, 10: 15731-15738.

Singh HP, Uma S, Selvarajan R, Karihaloo JL. 2011. Micro propagation for production of quality banana planting material in Asia-Pacific. Asia-Pacific Consortium on Agricultural Biotechnology (APCoAB), New Delhi, India, 92.

Singh TD, Singh CH, Nongalleima K, Moirangthem S, Devi HS. 2013. Analysis of growth, yield potential and horticultural performance of conventional vs. micro propagated plants of Curcuma longa var. Lakadong. Afr. J Biotechnol, 12: 16041608.

Singh VK, Prasad VM, Kumari S, Rajoriya P, Misra P. 2017. Identification of the suitable hardening protocol and hardening medium in micro propagation of gerbera (Gerbera jamesonii Bolus). International Journal of Current Microbiology and Applied Science, 6: 2476-2484.

Sipen P, Davey MR. 2012. Effects of N6-benzylaminopurine and indole acetic acid on in vitro shoot multiplication, nodule-like meristem proliferation and plant regeneration of Malaysian bananas (Musa spp.). Tropical life sciences research, 23: 67-80.

Smale M, Tushemereirwe W. 2007. An economic assessment of banana genetic improvement and innovation in the Lake Victoria region of Uganda and Tanzania (eds), International Food Policy Research Institute, Washington DC. 
Sumalatha A. 2016. Plant tissue culture of Banana in laboratory. Journal of Biotechnological Science, 3:54-62.

Thangavelu R, Mustaffa MM. 2012. Current advances in the Fusarium wilt disease management in banana with emphasis on biological control. In Plant pathology, 273-298.

Uzaribara E, Nachegowda V, Ansar H, Sathyanarayana BN, Taj A. 2015. In vitro propagation of red banana (Musa acuminata). International Quarterly Journal of Life Sciences, 10: $125-129$.

Venkatachalam L, Sreedhar R, Bhagyalakshmi N. 2007. Micro propagation in banana using high levels of cytokinin does not involve any genetic change as revealed by RAPD and ISSR markers. Plant Growth Regul, 51: 192-205.
Vuylsteke D.R.1998. Shoot-tip culture for the propagation, conservation and distribution of Musa germplasm. IITA.

Waman AA, Bohra P, Sathyanarayana BN. 2014. Not all sugars are sweet for banana multiplication. In vitro multiplication, rooting and acclimatization of banana as influenced by carbon sources-concentrations interactions. In Vitro Cellular \& Developmental Biology-Plant, 50:552-560.

Xiansong Y. 2010. Rapid production of virus-free plantlets by shoot tip culture in vitro of purple-coloured sweet potato (Ipomea batata (L.) Lam.). Pak J Biotechnol, 42: 2069-2075. 